\title{
Proceedings of the XXIInd Congress of the International Primatological Society, Edinburgh International Conference Centre, Edinburgh, Scotland, August 3-8, 2008
}

\author{
Nancy G. Caine • Elisabetta Visalberghi • Steven J. Schapiro • \\ Katherine A. Leighty
}

Received: 25 November 2010 /Accepted: 25 November 2010 /

Published online: 5 January 2011

(C) Springer Science+Business Media, LLC 2010

\section{Minutes of the Pre-Congress Council Meeting, August 3, 2008}

Attending (in alphabetical order):

Debbie Cox (Incoming VP for Captive Care)

Julia Fischer (German Primate Society)

Dorothy Fragaszy (past President, Ex-officio)

Paul Honess (for the organizing committee of the 2008 Congress in Edinburgh, Scotland)

Hiroshi Ihobe (for the organizing committee of the 2010 Congress in Kyoto, Japan)

Peter Kappeler (VP for Research)

Katie Leighty (VP for Communications)

Ann MacLarnon (Primate Society of Great Britain)

Colleen McCann (VP for Captive Care)

\footnotetext{
N. G. Caine $(\bowtie)$

Department of Psychology, California State University San Marcos,

333 S. Twin Oaks Valley Rd, San Marcos, CA 92096-0001, USA

e-mail: ncaine@csusm.edu

E. Visalberghi

Consiglio Nazionale delle Ricerche, Istituto di Scienze e Tecnologie della Cognizione,

Via Ulisse Aldrovandi 16B, Roma 00197, Italy

\section{S. J. Schapiro}

Department of Veterinary Sciences, University of Texas M.D. Anderson Cancer Center,

Bastrop, TX, USA

K. A. Leighty

Department of Education and Science, Disney's Animal Kingdom ${ }^{\mathbb{R}}$, Orlando, FL, USA
} 
Ivan Lledo (Asociacion Primatologica Espanola)

Elizabeth Lonsdorf (Incoming VP for Education)

Ernesto Rodriguez Luna, Aralisa Shedden, \& Jorge Martinez Contreras (presenting the bid for the 2012 Congress in Veracruz, Mexico)

Vicky Melfi (reporting on the 2008 IPS Training Program)

Vernon Reynolds (reporting on the CCI Policy Statement)

Steve Ross (for the position statement on inappropriate portrayal of primates in the media) Anthony Rylands (Primate Specialist Group, Species Survival Committee, IUCN)

Anne Savage (VP for Education)

Steve Schapiro (Treasurer \& Vice President for Membership)

Suzette Tardif (American Society of Primatologists)

Trudy Turner (Primate Ecology and Genetics Group, South Africa)

Elisabetta Visalberghi (Secretary General)

Augusto Vitale (European Federation of Primatology)

Richard Wrangham (President)

Juichi Yamagiwa (Incoming President and Primate Society of Japan)

I. The meeting was called to order at $0900 \mathrm{~h}$ by President Wrangham and introductions were made. President Wrangham began by thanking the Organizing Committee and the Primate Society of Great Britain for hosting the 2008 Congress.

II. The minutes of Council and General Assembly meetings, published in the Proceedings of the XXI Congress of the International Primatological Society, in the IPS Bulletin 2006, 32(2), 6-17, and in the International Journal of Primatology 2008, 29, 273-287 were unanimously approved.

III. Executive Council Reports

A. President (R. Wrangham).

1. Following the 2006 Congress, President Wrangham organized an IPS vote on the signing of the Kinshasa Declaration. The IPS membership voted to sign the Declaration.

2. Candidates submitted by GrASP for the new slate of the GrASP Scientific Commission were vetted by President Wrangham, and Mark Leighton was nominated to represent the IPS President.

3. President Wrangham chaired the nominating committee for the new Council, and the committee to select the recipient of the Lifetime Achievement Award.

4. President Wrangham offered his thanks to the members of the Council who have worked so hard and so successfully for the past 4 years.

B. Secretary General (E. Visalberghi). In addition to keeping the records of the IPS, assisting with the organization of Congresses, and maintaining contact with the affiliated societies, Secretary General Visalberghi supervised the election processes for Council offices and constitution/bylaws changes.

C. Treasurer and VP for Membership (S. Schapiro)

1. VP Schapiro reported membership figures, showing that the IPS has increased its membership since the 2006 Congress. Seven affiliated 
societies currently meet the requirements for voting membership on the IPS Council (see minutes of the General Assembly for details).

2. IPS receives US\$2 for every subscription to the International Journal of Primatology that is sold to members via the IPS website. So far, 190 IPS members have purchased IJP subscriptions for 2008.

3. Treasurer Schapiro reported on the financial status of IPS, which remains healthy (see minutes of the General Assembly for details). Most of our expenses are associated with conservation initiatives.

4. Projected budgets for the next 2 years suggest that expenditures may exceed revenue by $\$ 11,350$ in 2008, depending on the financial outcome of the Congress in Edinburgh. Revenue is likely to exceed expenses by about $\$ 3200$ in 2009. Please note that IPS has substantially increased the amount of money provided for grants in Education, Research, and Captive Care in 2007 and 2008 and plans to continue this trend in 2009 (and beyond).

5. The revenue enhancement plan, begun in 2002, continues to be quite successful. We have increased membership revenue through a variety of mechanisms. One hundred and twenty-nine (129) extremely committed members of IPS have purchased Full or Partial Lifetime Memberships. Their financial commitment to IPS allows us to maintain a firm foundation for the Society's business functions. Revenue sharing from IPS Congresses was another component of the 2002 revenue enhancement plan. The 2006 Congress in Entebbe was extremely profitable, generating more than $\$ 80,000$ to be strategically utilized to support enhancements to the Education, Research, Conservation, and Captive Care funding mechanisms. As stated 2 years ago, "If we take in more money, we can and will spend more money on important initiatives." We have done this.

6. VP/Treasurer Schapiro listed his goals for the next 2 years (see minutes of the General Assembly for details).

7. In the future, the Treasurer will send a copy of the Treasurer's report in advance of the Council meeting, to give the Council more time to process the information. The IPS Constitution requires an audit of the IPS "books" only when there is a change in Treasurer.

D. VP for Conservation (J. Ratsimbazafy)

1. VP Ratsimbazafy reported that it was a great pleasure for him to see that many young primatologists are devoted to conservation. He received 50 applications for both Conservation grants (46 applications) and the Martha J. Galante Award (4 applications) in 2007, whereas in the previous year (2006) there were only 20 applications. Owing to the increase of the number of applicants, the IPS Council agreed to award 7 applications (see minutes of the General Assembly for names of grant recipients).

2. Reviewers of the grant applications had several comments and suggestions regarding the review process for the Conservation grants and Galante Award, including the recognition that applicants from some developing countries are at a disadvantage in terms of their experience in preparing a sufficiently detailed proposal. IPS will consider posting successful grants 
on the website to aid applicants in preparing excellent proposals. There was also a discussion of the role of training and applied conservation in a successful Galante application.

3. Members of the Conservation Committee and ad hoc grant reviewers were sincerely thanked by VP Ratsimbazafy.

\section{E. VP for Education (A. Savage)}

1. VP Savage reported that the Lawrence Jacobsen Education Development Award supports the initiation and long-term support of primate conservation education programs. This education award supports field conservation programs, work with local communities and schools, or provides training in conservation education techniques. Recipients of the awards for 2007 and 2008 were announced (see minutes of the General Assembly for names of grant recipients).

2. In honor of Dr. Charles Southwick's longstanding commitment to conservation education, IPS created the Charles Southwick Conservation Education Commitment Award. This award is dedicated to recognizing individuals living in primate habitat countries who have made a significant contribution to formal and informal conservation education in their countries. Recipients of the award for 2007 and 2008 were announced (see minutes of the General Assembly for names of award recipients).

3. In collaboration with the University of St. Andrews Centre for Research into Ecological and Environmental Modeling, a successful pre-Congress workshop, "Collection and Analysis of Field Data for Estimation of Primate Density or Abundance," was held. Twenty-four participants from various countries learned from experts in the field and exchanged valuable information in an effort to develop effective census techniques that provide accurate estimates of primate abundance.

4. VPs Katie Leighty and Anne Savage will lead the "Professional Development for Young Primatologists: The Keys to Success" workshop at the current Congress.

5. VP Savage offered her sincere thanks to the dedicated members of the education committee throughout her 8 years of service as VP for Education: Gustl Anzenberger, Tammie Bettinger, Barb Cartwright, Mukesh Chalise, Ilke Herbinger, Alison Jolly, Laura Marsh, Lynne Miller, Marc Myers, and Hanta Rasamimanana.

\section{F. VP for Captive Care (C. McCann)}

1. VP McCann reported on the translations of The IPS International Guidelines for the Acquisition, Care and Breeding of Nonhuman Primates (see minutes of the General Assembly for details).

2. The committee granted 3 awards in each of the last 2 grant rounds (see minutes of the General Assembly for names of grant recipients).

3. For the current Congress Colleen McCann and Hannah Buchanan-Smith have organized a symposium on the application of the IPS Guidelines for Captive Care. Each Captive Care committee member is an author on 1 of 
the 6 presentations, which covered a wide range of captive care issues across diverse primate facilities.

4. VP McCann acknowledged the Captive Care Committee members for their hard work and professionalism in this committee, and in doing so, making a great contribution to captive primates on behalf of the IPS. They are: Hannah-Buchannan-Smith, Kay Farmer, Helena Fitch-Snyder, Lisa Jones-Engel, Mark Prescott, and Larry Williams.

G. VP for Research (P. Kappeler)

1. VP Kappeler reported on research grants awarded in 2007 and 2008 (see minutes of the General Assembly for names of grant recipients).

2. There were 249 entries in the Student Competition at this year's Congress. Eighteen countries are represented in the oral presentation category and 19 countries are represented in the poster category. The large number of entries required the recruitment of 85 judges from 19 countries such that there could be 3 scorers per talk or poster. The number of entrants and judges has become unwieldy, and mechanisms were suggested to reduce the burden while maintaining a high-quality competition (see minutes of the Post-Congress Council meeting for details on changes to the student competition process).

3. VP Kappeler thanked his committee, composed of Eduardo FernandezDuque, Chuck Snowdon, Joanna Setchell, Russ Tuttle, Steve Schapiro, Tetsuro Matsuzawa, Richard Wrangham, Frans de Waal, and Emilia Yamamoto.

\section{H. VP for Communications (K. Leighty)}

1. VP Leighty thanked all members of the Council and the IPS membership for their submissions to the IPS Bulletin.

2. VP Leighty announced that the IPS Bulletin will now be in electronic format, available to members via the IPS website. An email to all members will announce the posting of each issue.

3. VP Leighty reported that the IPS website was redesigned over the last year with the work Dean Wilcox of Wilcox Designs and Nancy Capitanio.

4. The new website was also used to conduct electronic voting in the 2008 Council election. Upgrades to the website to allow this functionality were made by Nancy Capitanio.

IV. Report from the IUCN Primate Specialist Group (A. Rylands). Dr. Anthony Rylands presented the IUCN/SSC Primate Specialist Group report for 20072008. An abridged version of the report is appended to these minutes.

\section{Reports from Affiliated Societies}

A. European Federation of Primatology (A. Vitale).

1. The 3rd Congress of the European Federation of Primatology will be held in Zurich from August 12 to 15, 2009. 
2. Folia Primatologica will continue to be the official journal of the Federation

3. The Federation has had an active role in the development of the norms and legislation related to the protection of nonhuman primates utilized in research laboratories.

B. Asociacion Primatologica Espanola (APE) (I. Lledo). Ivan Lledo stated that Spanish and Portuguese primatologists will meet every 2 years and that the next meeting will be in Madrid. Moreover, APE has a new website and it is preparing a list of the captive primates in Spain.

C. Primate Ecology and Genetics Group, South Africa (T. Turner). Trudy Turner informed the Council that whereas in 2002 only 12 people attended the meeting of their organization, last year the number attending was about 50 .

D. Primate Society of Japan (J. Yamagiwa). Juichi Yamagiwa of the Primate Society of Japan stated his goal of increasing the number of Japanese members of IPS.

\section{Future Congresses}

A. Hiroshi Ihobe reported on the progress made by the Japanese team for the organization of the XXIIIth Congress in Kyoto, Japan, in 2010. The meeting will be at the Yoshida Campus of Kyoto University, September 1218, 2010. As requested by the IPS Council, the fees will be kept low so that as many primatologists as possible can attend. The abstracts will once again be made available on a CD.

B. Ernesto Rodriguez Luna, Aralisa Shedden, and Jorge Martinez Contreras presented their bid to host the XXIVth Congress in Veracruz, Mexico. The venue will be the World Trade Center Veracruz, which is close to many hotels and inexpensive accommodations. Costs of food and lodging will be low, helping to offset the registration fee. The organizers are looking for financial support from the government of Mexico, and this may help them to reduce costs for participants.

C. After some discussion the bid was accepted with the advice that the organizers take advantage of the experience of previous organizers by discussing their plans with them, especially in terms of ways that costs of attending can be reduced. Treasurer Schapiro also noted that IPS meetings should be an occasion for the IPS to make money (so that the money can be spent for the many awards granted by the Society). This was indeed the case in Uganda and should be the case in Edinburgh as well.

\section{New Business}

A. President Wrangham proposed that the new Council update and improve the guidelines that are provided to those who place a bid for hosting an IPS Congress. He also suggested that each IPS president be asked to present a Plenary Lecture at one of the Congresses that is held during her/his term.

B. International Journal of Primatology. Council did not receive a report from the Editor.

C. Council discussed the draft Position Statement, Improving Primate Conservation Through Community Involvement, prepared by Vernon 
Reynolds and Tammie Bettinger. Council voted unanimously to present the draft to the General Assembly for a vote.

D. Vicky Melfi reported that the IPS Training Program ("Improving Primate Welfare Through Behavioural Husbandry"), held in the Edinburgh Zoo, was a great success. There were 16 delegates from 11 countries in attendance.

E. There was some discussion of developing a statement regarding compliance with captive primate welfare regulations that would accompany submissions to IJP. Incoming President Yamagiwa and VP for Research Kappeler will give further consideration to this matter.

F. Valérie Dufour, also on behalf of Bernard Thierry, Odile Petit, and their colleagues, visited the Council meeting to discuss an impending action at the primate center at the Université Louis Pasteur, Strasbourg. A group of 14 healthy Tonkean macaques that are herpes B positive face the risk of being euthanized because they are perceived to be a threat to humans. The group is isolated under controlled conditions and reproduction has been halted. Recognizing that many institutions successfully and safely hold B-positive primates, the Council agreed to send a letter to the president of the university to argue strongly against the euthanasia of these monkeys.

G. Elizabeth Lonsdorf (also on behalf of Steve Ross) presented a draft position statement on the inappropriate portrayal of primates in the media. The statement is intended to discourage the use of nonhuman primates as performers, photo props, and actors. The Council voted unanimously to present a draft statement to the General Assembly for a vote by the membership.

After setting the agenda for the General Assembly, the meeting was adjourned at $1700 \mathrm{~h}$.

\section{Minutes of the IPS General Assembly, August 7, 2008}

President Richard Wrangham called the meeting to order at $1600 \mathrm{~h}$.

I. Executive Council Reports

A. President (R. Wrangham).

1. President Wrangham offered his thanks to the members of Council who have worked so hard and so successfully for the past 4 years.

2. Following the 2006 Congress, President Wrangham organized an IPS vote on the signing of the Kinshasa Declaration. The IPS membership voted to sign the Declaration.

3. Candidates submitted by GrASP for the new slate of the GrASP Scientific Commission were vetted by President Wrangham, and Mark Leighton was nominated to represent the IPS President.

4. President Wrangham chaired the nominating committee for the new Council, and the committee to select the recipient of the Lifetime Achievement Award.

B. Secretary General (E. Visalberghi). Secretary Visalberghi reported that two elections were successfully run since the last Congress: an election to make 
changes to the IPS Constitution and Bylaws and the new Council elections. She also helped to organize the Edinburgh Congress and has worked on the Kyoto Congress planning as well.

C. Treasurer and VP for Membership (S. Schapiro).

1. The 2006 Congress in Entebbe netted more than $\$ 80,000$ in profit for IPS. Debby Cox and William Olupot are to be congratulated for organizing the Congress and for making such a substantial profit.

2. As of the 2006 Congress membership in IPS stood at 1040. As of the current Congress, membership stands at 1474.

3. We have seven affiliated societies that have votes on Council: Congolese, American, German, Japanese, British, European Federation, and Spanish.

4. The total of all IPS funds as of December 31, 2007 is $\$ 283,717$. This reflects a steady growth over the past few years, with a "bump" from the profit from the 2006 Congress.

5. IPS spends about $\$ 54,000 /$ year in grants, awards, and for the pre-Congress training programs.

6. In 2007 , IPS took in about $\$ 70,000$ and spent about $\$ 68,000$. Treasurer Schapiro expects an income of about \$92,000 during 2008 (not including any profits from the 2008 Congress) and expects to spend about $\$ 103,000$.

7. Short-term goals are:

a. Encourage more contributions to the Conservation Fund

b. Encourage more Lifetime Memberships

c. Facilitate affiliated society membership in IPS

d. Search for new contributors

e. Invest money from General Fund

f. Achieve a profit from IPS 2008

g. Facilitate lower registration fees for future Congresses

8. Long-term goals are to increase revenue to increase support of missionrelevant programs.

D. VP for Communications (K. Leighty)

1. The IPS Bulletin will no longer be mailed to members. Instead, it will be posted to the IPS website and will be accessible with username and password. Members will receive an email when new issues are posted.

2. The website was updated and enhanced. There are more improvements to come.

3. Online balloting was accomplished for the elections

4. The silent auction raised $\$ 4400$ for the Conservation Fund at this Congress.

E. VP for Education (A. Savage)

1. The Jacobsen Award Winners for 2007 and 2008 were Cristos Astaras, Marina Cords, and Damodar Gaire (for 2007) and Sian Sara Waters, Allai, Orimba, Tricia Parish, and Corrin La Combe (for 2008). 
2. The Southwick Award for 2007 went to Jerry Akparawa. The 2008 winners were Pierrot Mbonzo and Mugabe Robert/Byamukama Lawrence.

3. A successful workshop was held before the Congress at the University of St. Andrews. The topic was collection and analysis of field data for the estimate of primate density and abundance.

F. VP for Conservation (J. Ratsimbazafy)

1. There was a great increase in applications for conservation grants and Galante awards. Reviewers of the applications were thanked.

2. Conservation grants were awarded to Abby Baird, Catherine Cooke, Antje Engelhart, Nguyen Manh Ha, Stacy Lindshield, Alexandre Nascimento, and Felicia Ruperti in 2007. In 2008 grants were awarded to Juliet Wright, Frank Cuozzo, Sara Hsiao, Riccardo Pansini, James Robins, Suzanne Hagell, and Tumukunde Alex. Galante awards were given to Martin Kowalewski and Ndeloh Etiendem in 2007 and 2008, respectively.

\section{G. VP for Captive Care (C. McCann)}

1. The second edition of the IPS Guidelines for Captive Care has been posted on the IPS website. A French translation by Marie Herrenschmidt has been completed and a Spanish version by Yvan Lledo-Ferrer is in progress.

2. Captive care grants were given to Sagan Friant, Doug Cress, and Natalia Ceballos-Mago in 2007 and to Claire Coulson/Doug Cress, Noruki Morimura, and Suzanne Turnock in 2008.

H. VP for Research (P. Kappeler)

1. Forty-nine applications for research grants were received in 2007 and seven grants were awarded. The recipients were Alison Behie, Sarah Carnegie, Marietta Dindo, Kathelijne Koops, Marie Pele, Fiona Stewart, and Michael Wasserman. In 2008, 65 applications were received and 7 grants were awarded. The recipients were Mary Blair, Kimberly Dingess, Michelle Brown, Mackenzie Bergstrom, Robin Bernstein, Cynthia Thompson, and Lauren Brent.

2. The Research Committee organized the student paper competition for the 2008 Congress. A total of 97 posters and 152 oral papers were judged. Winners will be announced at the banquet.

\section{Report from IUCN Primate Specialist Group (A. Rylands)}

A. The Red List for 2008 will become official in October. The number of threatened (Critically Endangered, Endangered, and Vulnerable categories) primate species will be 303 , which is $48 \%$ of all known primate species.

B. Conservation International's (CI) fifth iteration of the list of the 25 most endangered species was determined with input from IPS. The list includes two new species from Madagascar, two from Asia, and one each from Africa and the Neotropics. 
III. The IPS Training Program (V. Melfi). This year the program's title was "Improving Primate Welfare through Behavioural Husbandry." Sixteen delegates from 11 countries were brought to Edinburgh to participate in the training.

IV. Planning for the 2010 Congress (J. Yamagiwa). The XXIII Congress of the IPS will be held September 12-18 at Kyoto University's Yoshida campus. The Secretary General of the Congress, Naofumi Nakagawa, was introduced and gave a short presentation about the venue. Questions from the Assembly addressed the need for child care, the cost and availability of accommodations, and problems with requiring credit cards to register. The organizing committee will consider these concerns in its planning.

V. The 2012 Congress will be held in Veracruz, Mexico. The dates are to be determined but will most likely be in June.

VI. Draft position statement: Improving Primate Conservation through Community Involvement

A. History. At the 2006 Congress there was a round table discussion about the importance of involving local communities in research projects. President Wrangham agreed to appoint Tammie Bettinger and Vernon Reynolds as cochairs of an ad hoc committee to develop a position statement and guidelines on this topic. An "e-committee" of some 70 people developed the following position statement, which was entered as a motion to the floor:

"The IPS recommends that, when conducting field studies, researchers consider including some provision for conservation through community involvement."

B. Discussion of the motion included these questions: Should the statement be limited to just research? Should the statement be more global in scope? Why does the statement only "recommend" that such involvement be "considered" rather than require it? Tammie Bettinger and Vernon Reynolds replied that some investigators (e.g., students) may not be in a position to implement community involvement and should not be penalized for failing to so. The recommendation is intended to be specific to research and to local communities; global initiatives are more in line with larger agencies.

C. President Wrangham called for a vote. A show of hands indicated clear majority support for the motion. THE MOTION PASSED and will be entered on the website as an IPS position statement, along with recommendations for how community involvement can be accomplished.

\section{Draft Position Statement: Inappropriate Use of Primates in the Media}

A. History. In response to an ad published in Science, President Wrangham wrote a letter on behalf of IPS to express concern about the consequences of inaccurate portrayals of primates in the media. Science withdrew the ad, which showed a chimpanzee dressed in a hat, reading a newspaper. People 
tend to underestimate the endangered status of chimpanzees in part because chimpanzees are so often seen in advertisements, movies, and television shows (Ross et al. 2008).

B. A motion was made that IPS adopt the following position statement:

WHEREAS live nonhuman primates are often portrayed in the media as frivolous caricatures of humans, dressed in clothing and trained to do tricks on command for the amusement of the general public but with disregard to the welfare and conservation consequences; and

WHEREAS many nonhuman primates used as actors in movies and television and as photo props for commercials and greeting cards are often removed from their mothers shortly after birth and are denied opportunities for normal social and psychological development; and

WHEREAS the use of nonhuman primates in this industry often involves aversive techniques to maintain control of these animals; and

WHEREAS the inappropriate portrayal of nonhuman primates inaccurately conveys their biology and conservation status and may affect public attitudes including those in range countries where interactions with these animals have potential damaging consequences; and

WHEREAS evidence suggests that many nonhuman primate species are susceptible to many of the pathogenic infections that afflict humans and the transmission of infection can occur in both directions, especially in performing circumstances in which primates are in direct proximity with public audiences including children and the elderly,

\section{The International Primatological Society therefore opposes the use of nonhuman primates as performers, photo props or actors}

C. By a vote of hands, the motion PASSED unanimously and will be posted on the IPS website.

VIII. Closing remarks by President Wrangham and Council transition. The President reminded the membership that Toshisada Nishida was given the IPS Award for Lifetime Achievement this year. He also thanked Paul Honess and the 2008 Local Arrangements Committee for their excellent work in putting together one of the largest Congresses in IPS history this year. Finally, the President passed the gavel to the new IPS President, Juichi Yamagiwa, who then welcomed the incoming Council members: Secretary General Nancy Caine, Treasurer/VP for Membership Steve Schapiro, VP for Communications Katie Leighty, VP for Captive Care Debby Cox, VP for Education Elizabeth Lonsdorf, VP for Research Peter Kappeler, and VP for Conservation Janette Wallis.

IX. New President Yamagiwa spoke briefly of his hope to enhance research, international collaboration, and conservation during his term of office. He also spoke of the need to expand the role of primatology in understanding human behavior and social issues. He hopes to increase communication between IPS and the various national primate societies, and to build stronger alliances with the media. 
X. New Business. Ian Redmond presented the membership with information on the role of deforestation in climate change. He urged IPS and its individual members to become involved in international efforts to halt deforestation.

The meeting was adjourned at about $1825 \mathrm{~h}$.

\section{Minutes of the Post-Congress Council Meeting, August 9, 2008}

Attending (in alphabetical order):

Nancy Caine (Secretary General)

Debby Cox (VP for Captive Care)

Ann MacLarnon (PSGB representative)

Peter Kappeler (VP for Research)

Katie Leighty (VP for Communications)

Elizabeth Lonsdorf (VP for Education)

Hantanirina Rasamimanara (Groupe d'Etudes et de Recherches en Primatologie)

Jonah Ratsimbazafy (Groupe d'Etudes et de Recherches en Primatologie)

Anthony Rylands (Deputy Chair IUCN/SSC Primate Specialist Group)

Steve Schapiro (Treasurer, VP for Membership)

Janette Wallis (VP for Conservation)

Richard Wrangham (past President, ex officio)

Juichi Yamagiwa (President)

I. The meeting was called to order at $0900 \mathrm{~h}$ by President Yamagiwa and introductions were made.

II. VP Leighty briefly described the duties of each Council member and noted several tasks that need to be completed in the near future:

A. VPs should begin building committees. Note that March 1 is the deadline for grants, so committee membership needs to be established well in advance of grant reviews.

B. Reports from each Council member are included in each of the two bulletins produced each year. The next bulletin will be published in October. Council members should respond in a timely fashion to VP Leighty's request for those reports.

C. Council members are expected to attend each Congress. Each Council member is expected to contribute to the scientific program of each congress (e.g., a symposium or workshop, etc). Council members should please be thinking about their contributions well in advance of the Kyoto meeting.

D. Nominating committees for the Lifetime Achievement Award and Council elections will be established by President Yamagiwa.

E. Judging student papers/posters at the next Congress: see below for results of Council's discussion of this process.

III. The IPS Training Program (formerly known as the pre-congress workshop)

A. History. The IPS training program (IPSTP), held in conjunction with each Congress, was designed to be organized by one of the Council VPs, 
working with local organizing committees, to bring together 12-20 individuals for training in a topic relevant to the IPS mission. Costs of attending the meeting are paid by IPS, traditionally with the support of funds from the Margot Marsh Biodiversity Foundation. The trainees are primarily from habitat countries where access to such training opportunities is limited and travel to international meetings is financially impossible. The IPSTP is a large financial undertaking that is logistically difficult. However, the program has been very successful, as measured by the number of trainees who remain active in primatology, obtain IPS grants and awards, and return to give talks at future IPS meetings. The topic for the IPSTP has usually, but not always, been related to conservation. The 2008 topic was captive care.

B. It was decided that there should always be a member of Council, identified at the previous Congress, who serves as point person and establishes an IPSTP committee. At least one member of the Local Arrangements Committee will be on that IPSTP committee.

C. VP Wallis has already been speaking with colleagues in Japan about the 2010 IPSTP.

D. VP Lonsdorf offered to establish a database through which past and future IPSTP participants can be tracked.

E. It was noted that Congress workshops other than the IPSTP, held during, before, or after the Congress, are also welcomed. Workshops that target students/young scientists are particularly valuable.

\section{Primates as Pets}

A. We were visited by representatives from the Monkey Sanctuary Trust, Looe, Cornwall, UK, and the RSPCA. They detailed the lack of effective legislation/enforcement of laws in the UK regarding primates in private ownership. Before leaving, the guests asked IPS to consider signing their written statement ("Statement on the UK Primate Pet Trade") or, even better, to create a formal statement establishing a position against primates as pets that could then be used to aid in their efforts to limit ownership of primates to licensed and monitored individuals/entities.

B. The ensuing discussion began with the question of whether IPS council should act on local issues like this. Would national societies (in this case PSGB) be a better place to start? IPS should be wary about creating statements that might contradict the positions of affiliated societies. Furthermore, should IPS first establish a formal policy of its own regarding primates as pets?

C. Given that the Council believed that the content of the statement at hand is consistent with IPS positions on conservation and captive care, it was decided that Pres. Yamagiwa and PSGB will write a joint letter of support for the particular statement referred to above.

D. VPs Cox and Lonsdorf will then construct a draft of a position statement on primates as pets, taking guidance from existing documents (e.g., those written by AZA and ASP) on the topic. 


\section{Congress Planning Issues}

A. There is agreement that the Council needs to evaluate carefully and make changes and additions to the current bid package such that the process of selecting and planning Congresses is clearer and more comprehensive. Treasurer Schapiro, Secretary Caine, and VPs Cox and Leighty will work on a draft and return it to the Council. Issues subject to revision include:

1. Should we have both a Program Committee and a Local Arrangements Committee, such that the scientific program (calls for abstracts, abstract review, and assignment of papers/posters to sessions) and the local/social program (establishing venues, accommodation options, banquets/tours, etc.) will not fall entirely on the shoulders of the local hosts? It was agreed that the limited human and infrastructure resources available to some local hosts will not allow to them to handle the scientific portion of the planning (as was true in Uganda in 2006). Other sites may be able to handle both (as was true in Edinburgh 2008).

2. It was decided that IPS will remain flexible on the matter of responsibility for the scientific program, but that the Council should always be represented on Congress scientific committees so that the program is rooted in and is a reflection of IPS. For the 2010 Kyoto conference, VPs Leighty and Kappeler will represent the Council on the Program Committee.

B. Abstract review process. VP Kappeler asked if the Congress abstract review process was unnecessarily editorial (few abstracts are rejected but a sizeable number are returned to the authors for revision) and if the lag time between abstract submission and the Congress is unnecessarily long. The Council reached consensus that, insofar as the abstracts are published (e.g., in IJP, Folia Primatologica, or Primate Eye), they must be of high quality, thereby necessitating the current review process. The Council agreed that the lag time between submission and Congress means that abstracts are prone to be vague and sometimes inconsistent with the data that are ultimately presented, but increasingly it is the case that if an abstract is not accepted early, the authors will not have time to successfully request funding to travel to the meeting.

\section{Community Conservation Initiative (CCI)}

A. The newly endorsed policy on CCI (see minutes of the General Assembly) contains guidelines that will be placed on the website and serve not as IPS dictates but as "some guidelines" to follow.

B. As to IPS funding for CCI, the Council decided that at this point in time it will not hold a separate call for CCI funds but that room will be made on existing IPS grant proposal forms (conservation, captive care, research grants forms) that will allow people to identify a CCI component to their research and apply for a supplement to carry out such work. It will be made clear that a CCI component is NOT required for funding, nor will the CCI component (if there is one) be considered in the review of the body of the grant.

C. VP Leighty will add a CCI section to each proposal form. 
D. Council decided to set aside $\$ 5000$ to be used toward CCI supplements in the upcoming grant cycle.

VII. Student Paper and Poster Competition at the Congress

A. The large number of student presentations (152 oral and 97 posters) has made the process of judging those presentations unwieldy. Furthermore, it has been difficult to obtain timely information from local arrangements about which abstracts have been entered into the competition. Students cannot always afford expensive banquet tickets and so are not able to accept their awards in person.

B. It was decided that a new process will be put in place for the 2010 Congress. Specifically:

1. Council members who are serving on the local arrangements or program committees (see section V.A.1 above) will send all accepted student abstracts to VP Lonsdorf, who will then distribute the abstracts to her committee.

2. Approximately 10-20 semifinalists will be determined based on the quality of the abstract.

3. The semifinalists will be notified that they must submit a 3-page extended abstract to VP Lonsdorf. Those who do so will be considered finalists in the competition, and their presentations will be judged by members of Council and IPS committees.

4. We will announce the winners at the General Assembly, which will be on the last day of the Congress instead of in the middle. Finalists will be told in advance that they are expected to attend the General Assembly.

5. VP Leighty will see that the abstract form is amended to state clearly the new rules for the student competition.

VIII. Website Revisions

A. VP Leighty asked all Council VPs to look at their pages on the IPS website to suggest improvements and updates.

B. Secretary Caine will look at the affiliates page to see if we can provide additional exposure for the affiliates and their websites and to increase opportunities for coordination among the affiliates.

\section{Deforestation and Climate Change}

A. At the General Assembly Ian Redmond asked IPS to help promote the fact that forest destruction is an important contributor to climate change and that forest preservation be included as a mechanism to reduce climate change. The destruction of forests has obvious implications for conservation of primates. The Council discussed ways in which we might support the statement provided to us by Professor Redmond.

B. President Yamagiwa will send a letter in support of the statement (addressed to whomever Prof. Redmond believes to be most appropriate), cc'd to all affiliated societies.

C. In addition, VP Wallis will work with Prof. Redmond to adapt the statement for consideration as an IPS policy statement. 
X. New Business

A. Putting the Inappropriate Use of Primates in the Media policy to action. VP Lonsdorf will write a letter mentioning our newly enacted policy when she sees examples of images in the media that contradict IPS policy. The letter will go out with President Yamagiwa's signature.

B. It was suggested that the Council think of ways to exploit the fact that the next IPS is in Kyoto, site of the upcoming (2012) international meeting on climate change.

C. Should IPS have a volunteer public relations advisor? VP Leighty will investigate ways in which IPS can issue press releases. Also, Council VPs can participate in public relations efforts as needed.

D. Should IPS join with Conservation International (CI) to put an "ad" in the British Parliament magazine in light of upcoming parliamentary meetings that will likely address the British position on climate change? Referring to earlier discussions on local issues that are perhaps better addressed by an affiliated society, and given the expense of such an ad, the Council decided to decline the invitation unless CI believes our participation is particularly important. (NOTE: CI later communicated that it did not expect IPS involvement in this matter.)

E. International Journal of Primatology (IJP)

1. There was no report from the Editor on IJP actions (submissions, acceptances, publication lag time, etc.) at the Congress this year.

2. The Council will discuss with the Editor its feeling that IJP would benefit from the inclusion of a Council member on the editorial board.

3. Dieter Czeschlik, head of the Biology Division at Springer-Verlag, wants to establish an MOU with IPS regarding our collaboration in maintaining IJP. The Council welcomes a meeting with Mr. Czeschlik and hopes to also discuss with him the possibility of financial arrangements that are more favorable to IPS. President Yamagiwa, Treasurer Schapiro, and Secretary Caine will pursue these matters and the possible need for legal advice in establishing the financial arrangements we seek.

The meeting was adjourned at $1310 \mathrm{~h}$.

\section{Report on IUCN/SSC Primate Specialist Group Actions: 2007-2008}

Russell A. Mittermeier, John F. Oates, Liz Williamson, Sally Walker, Anthony B. Rylands

I. Structure

The PSG has a membership of about 400. The current officers are as follows:

Chair Russell A. Mittermeier, Conservation International, Arlington, VA, USA

Deputy Chair Anthony B. Rylands, Conservation International, Arlington, VA, USA

General Coordinator John M. Aguiar, Conservation International, Arlington, VA, USA

Coordinator, Section on Great Apes Liz Williamson, Stirling Univ., Scotland, UK Regional Coordinators: Neotropics

Ernesto Rodríguez-Luna, Erwin Palacios, Eckhard W. Heymann, M. Cecília M. Kierulff

Regional Coordinators: Africa 
John F. Oates, David Mbora, Jörg U. Ganzhorn

Regional Coordinators: Asia

Long Yongcheng, Jatna Supriatna, Christian Roos, Sally Walker

\section{Taxonomy}

The taxonomic list of primates maintained by the PSG currently indicates 405 species and 664 species and subspecies. This is rather more than was assessed by the IUCN Red List Program for the 2008 IUCN Red List of Threatened Species (see below). The discrepancy comes from differing taxonomies, most especially for the Asian primates, as well as a number of newly described primates that were not assessed.

\begin{tabular}{lllll}
\hline & Family & Genus & Species & Species and subspecies \\
Africa & 4 & 22 & 84 & 173 \\
Madagascar & 5 & 15 & 96 & 100 \\
Asia & 5 & 16 & 84 & 189 \\
Neotropics & 5 & 19 & 141 & 202 \\
Total & 6 & 71 & 405 & 664 \\
\hline
\end{tabular}

\section{New Species}

Thirteen primates - species and subspecies - were described during the period 2007-2008 (August): 8 from Madagascar, 1 from Africa, 1 from Asia, and 3 from the Neotropics. Eight of the primates described are prosimians (a potto, a mouse lemur, 2 bamboo lemurs, 2 sportive lemurs, and 2 woolly lemurs), and 4 are monkeys (a silvered langur, a night monkey, and 2 black uakaris).

\section{Madagascar}

Microcebus macarthurii Radespiel et al., 2008

Hapalemur griseus ranomafanensis Rabarivola et al., 2007

Hapalemur griseus gilberti Rabarivola et al., 2007

Lepilemur otto Craul et al., 2007

Lepilemur manasamody Craul et al., 2007*

Lepilemur scottorum Lei et al., 2008

Avahi betsileo Andriantompohavana et al., 2007

Avahi mooreorum Lei et al., 2008

\section{Asia}

Trachypithecus cristatus selangorensis Roos et al., 2008

Africa

Perodicticus potto stockleyi Butynski and De Jong, 2007

\section{Neotropics}

Aotus jorgehernandezi Defler and Bueno, 2007

Cacajao hosomi Boubli et al., 2008

Cacajao ayresi Boubli et al., 2008
Macarthur's mouse lemur

Ranomafana gray bamboo lemur

Gilbert's gray bamboo lemur

Otto's sportive lemur

Manasamody sportive lemur*

The Scott's sportive lemur

Betsileo woolly lemur

The Moore's woolly lemur

West Malaysian silvered langur

Mount Kenya potto

Hernández-Camacho's night monkey

Neblina black uakari

Ayres' black uakari

*Probably a junior synonym of Lepilemur grewcocki Louis Jr. et al., 2006. 
IV. IUCN/SSC Red List of Threatened Primates 2008

From 2005 to 2008, the threatened status of the primate species and subspecies was assessed against the IUCN/SSC Red List Categories and Criteria Version 3.1. The results for the great apes, except for eastern gorilla were published in September 2007. The assessments for the remaining primates were announced at a symposium during the XXIIth Congress of the International Primatological Society (IPS), Edinburgh, August 2008. The results of the assessment are available on the PSG website (http://www. primate-sg.org) and will be placed on the IUCN Red List website, along all other mammals, in early October 2008. The assessments were coordinated by the Biodiversity Assessment Unit of IUCN and the Center for Applied Biodiversity Science (CABS), Conservation International and included 4 workshops.

Of the 634 primate species and subspecies assessed, 303 now rank as threatened: $48 \%$ of all primates. Almost $11 \%$ are Critically Endangered, $21 \%$ are Endangered, and 15\% Vulnerable. Sixteen percent were not assessed (Data Deficient or Not Evaluated). Only 30\% of the primates were assessed as of Least Concern. Forty-five percent of the Malagasy lemurs were assessed as Data Deficient; only $8 \%$ were found to be of Least Concern. Seventy-one percent (120) of the 169 Asian primates are now considered threatened.

\begin{tabular}{llllllll}
\hline \multirow{2}{*}{ Africa } & Taxa & Sp. & $\mathbf{C R}$ & $\mathbf{E N}$ & $\mathbf{V U}$ & $\mathbf{E N}$ & VU+EN+CR \\
& $\mathbf{1 7 0}$ & $\mathbf{8 3}$ & $\mathbf{1 2}$ & $\mathbf{3 0}$ & $\mathbf{2 1}$ & $\mathbf{3 0}$ & $\mathbf{6 3}$ \\
Madagascar & $\mathbf{9 6}$ & $\mathbf{9 2}$ & $\mathbf{7}$ & $\mathbf{1 9}$ & $\mathbf{1 5}$ & $\mathbf{1 9}$ & $\mathbf{4 1}$ \\
& & & $7 \%$ & $20 \%$ & $16 \%$ & $20 \%$ & $43 \%$ \\
Asia & $\mathbf{1 6 9}$ & $\mathbf{9 7}$ & $\mathbf{2 5}$ & $\mathbf{6 4}$ & $\mathbf{3 1}$ & $\mathbf{6 4}$ & $\mathbf{1 2 0}$ \\
& & & $15 \%$ & $38 \%$ & $18 \%$ & $38 \%$ & $71 \%$ \\
Neotropics & $\mathbf{1 9 9}$ & $\mathbf{1 4 0}$ & $\mathbf{2 5}$ & $\mathbf{2 4}$ & $\mathbf{3 0}$ & $\mathbf{2 4}$ & $\mathbf{7 9}$ \\
& & & $13 \%$ & $12 \%$ & $15 \%$ & $12 \%$ & $39 \%$ \\
Total & $\mathbf{6 3 4}$ & $\mathbf{4 1 2}$ & $\mathbf{6 9}$ & $\mathbf{1 3 7}$ & $\mathbf{9 7}$ & $\mathbf{1 3 7}$ & $\mathbf{3 0 3}$ \\
& & & $10.9 \%$ & $21.6 \%$ & $15.3 \%$ & $21.6 \%$ & \\
\hline
\end{tabular}

$\mathrm{CR}=$ Critically Endangered, $\mathrm{EN}=$ Endangered, $\mathrm{VU}=$ Vulnerable, $\mathrm{NT}=$ Near Threatened, $\mathrm{LC}=$ Least Concern, DD = Data Deficient, $\mathrm{NE}=$ Not evaluated.

Section on Great Apes (SGA) (Liz Williamson)

\section{A.P.E.S. Database}

The SGA now comprises 102 members, with an Executive Committee of 22. In 2006, researchers from the Max Planck Institute initiated the A.P.E.S. database (http://apes.eva.mpg.de) in collaboration with the SGA. Existing survey data of the great apes are being compiled, recording presence/absence; spatial trends in ape populations, temporal trends in ape populations; estimates of population sizes, ultimately to provide an accurate picture of the distribution and abundance of great apes, and thus inform long-term management and conservation strategies. This project will also collect new field data, with a particular emphasis on the assessment of global status of all ape species. The A. 
P.E.S. website features an interactive map that links survey data to geographic locations, providing a user-friendly means for searching by country or region. So far, the database developers have focused on cataloguing published surveys and soliciting researchers to contribute any data available. Approximately, 200 surveys of gorillas and chimpanzees have been listed, with a further 300 thought to exist but yet to be acquired. The database is being expanded to include bonobos and orangutans, and survey information from Malaysia and Indonesia is being entered.

\section{Best Practice Guidelines for the Conservation of Great Apes}

The goal of this series is to address cutting-edge issues in great ape conservation, and develop consensus through the publication of guidelines or best practices on priority issues, providing guidance not only to great ape scientists and researchers in the field, but also to development organizations, donors, and governments involved in projects concerning great apes. The publications are endorsed by the IUCN and the series editor is Liz Williamson. Three were published in 2007 and 2008 (available on the PSG website http:// www.primate-sg.org).

Morgan, D., and Sanz, C. (2007). Best Practice Guidelines for Reducing the Impact of Commercial Logging on Great Apes in Western Equatorial Africa. Occasional Paper of the IUCN Species Survival Commission (34): 32 pp. IUCN/SSC Primate Specialist Group, Gland, Switzerland. (Also in French)

Beck, B., Walkup, K., Rodrigues, M., Unwin, S., Travis, D., and Stoinski, T. (2007). Best Practice Guidelines for the Re-introduction of Great Apes. Occasional Paper of the IUCN Species Survival Commission (35): 48 pp. IUCN/SSC Primate Specialist Group, Gland, Switzerland. (Also in French)

Kühl, H., Maisels, F., Ancrenaz, M., and Williamson, E. A. (2008). Best Practice Guidelines for Surveys and Monitoring of Great Ape Populations. Occasional Paper of the IUCN Species Survival Commission (36): 28 pp. IUCN/SSC Primate Specialist Group, Gland, Switzerland.

\section{The World's 25 Most Endangered Primates 2008-2010}

The biennial listing of the World's 25 Most Endangered Primates draws attention to the species that are highly threatened, currently lacking adequate national and international attention for their conservation, and most in need of further research and protection. The PSG, Conservation International, and the International Primatological Society (IPS) joined forces in 2004 to draw up and publicize this list. The 2008-2010 list was drawn up during the XXIIth Congress of the International Primatological Society, Edinburgh 2008.

$\begin{array}{lll}\text { Madagascar } & & \\ \text { Prolemur simus } & \text { Greater bamboo lemur } & \text { Madagascar } \\ \text { Eulemur cinereiceps* } & \text { Gray-headed lemur* } & \text { Madagascar } \\ \text { Eulemur flavifrons } & \text { Sclater's lemur } & \text { Madagascar } \\ \text { Propithecus candidus } & \text { Silky sifaka } & \text { Madagascar } \\ \text { Lepilemur septentrionalis } & \text { Northern sportive lemur } & \text { Madagascar }\end{array}$




\begin{tabular}{|c|c|c|}
\hline \multicolumn{3}{|l|}{ Africa } \\
\hline Galagoides rondoensis & Rondo dwarf galago & Tanzania \\
\hline Cercopithecus diana roloway & Roloway monkey & Côte d'Ivoire, Ghana \\
\hline Procolobus rufomitratus & Tana River red colobus & Kenya \\
\hline Procolobus pennantii epieni & Niger Delta red colobus & Nigeria \\
\hline Rungwecebus kipunji & Kipunji & Tanzania \\
\hline Gorilla gorilla diehli & Cross River gorilla & Cameroon, Nigeria \\
\hline \multicolumn{3}{|l|}{ Asia } \\
\hline Tarsius sp. & Siau Island tarsier & Indonesia (Siau Is.) \\
\hline Nycticebus javanicus & Javan slow loris & Indonesia (Java) \\
\hline Simias concolor & Pig-tailed langur & Indonesia (Mentawai Is.) \\
\hline Trachypithecus delacouri & Delacour's langur & Vietnam \\
\hline Trachypithecus p. poliocephalus & Golden-headed Langur or Cat Ba Langur & Vietnam \\
\hline Semnopithecus vetulus nestor & Western purple-faced langur & Sri Lanka \\
\hline Pygathrix cinerea & Grey-shanked douc & Vietnam \\
\hline Rhinopithecus avunculus & Tonkin snub-nosed monkey & Vietnam \\
\hline Nomascus nasutus & Cao-Vit black-crested gibbon & China, Vietnam \\
\hline Hoolock hoolock & Western Hoolock gibbon & Bangladesh, India, Myanmar \\
\hline Pongo abelii & Sumatran orang-utan & Indonesia (Sumatra) \\
\hline \multicolumn{3}{|l|}{ Neotropics } \\
\hline Saguinus oedipus & Cotton-top tamarin & Colombia \\
\hline Ateles hybridus & Variegated spider monkey & Colombia, Venezuela \\
\hline Oreonax flavicauda & Peruvian yellow-tailed woolly monkey & Peru \\
\hline
\end{tabular}

*Previously called Eulemur albocollaris (Rumpler, 1975), but now considered a junior synonym. The following species were added: Sclater's lemur (Eulemur flavifrons), the northern sportive lemur (Lepilemur septentrionalis), the Niger Delta red colobus (Procolobus pennantii epieni), the Javan slow loris (Nycticebus javanicus), the Cao-Vit crested gibbon (Nomascus nasutus), and the cottontop tamarin (Saguinus oedipus).

The following species were taken off the list: the Sahamalaza sportive lemur (Lepilemur sahamalazensis), Pennant's red colobus (Procolobus pennantii pennantii), Miss Waldron's red colobus (Procolobus badius waldronae), the brown-headed spider monkey (Ateles fusciceps), the Horton Plains slender loris (Loris tardigradus nycticeboides), and the Hainan gibbon (Nomascus hainanus).

VIII. PSG and the South Asian Primate Network - SAPN (Sally Walker)

The South Asian Primate Network (SAPN) of the PSG was set up by Sally Walker, Sanjay Molur, and other members of the Zoo Outreach Organisation (ZOO) (http://www.zooreach.org). South Asia includes Afghanistan, Bhutan, Bangladesh, India, Maldives, Nepal, Pakistan and Sri Lanka. The SAPN website (http://www.southasianprimatenetwork.org) was launched in December 2006. ZOO and the Wildlife Information Liaison Development (WILD) have developed a database that includes the taxa assessed in CAMP workshops: the Threatened Taxa Monitoring System (TTMS) has all the data sheets for all the South Asian taxa assessed for their threatened status (http://www.southasiantaxa. org). The website http://www.zooreach.org/Networks/Primate/Primate directory.pdf provides a directory of of the SAPN members. Besides providing a forum for information exchange, the SAPN helps raise funds for, and 
promotes, workshops and research, and produces publications and educational materials for the conservation of the South Asian primates.

ZOO and WILD held a series of 6 conservation educator training workshops entitled "Helping Hoolock Gibbons Hang On" February 1-28, 2007. They were sponsored by The Great Ape Conservation Fund of the U.S. Fish and Wildlife Service (USFWS). They were held in Assam for Northeastern Indian participants: Jalukbari, Nameri National Park, Manas National Park, Tinsukia, Silchar, and Guwahati. The theme was the highly threatened hoolock gibbon (Hoolock hoolock), with particular reference to shared hoolock and tiger localities.

Molur, P. B. (2005). People for Primates - into Action: Educational Guidelines and Techniques on Behalf of South Asian Primates. Zoo Outreach Organisation (ZOO) and PSG South Asian Primate Network (SAPN), Coimbatore, India. $64 \mathrm{pp}$.

Website: http://www.southasianprimatenetwork.org/pdf/Primate\%20Edu cation $\% 20$ Manual.pdf

Molur, S., Brandon-Jones, D., Dittus, W., Eudey, A., Kumar, A., Singh, M., Feeroz, M. M., Chalise, M., Priya, P., and Walker, S. (2003). Status of South Asian Primates: Conservation Assessment and Management Plan (C.A.M.P.) Workshop Report. Zoo Outreach Organisation (ZOO), CBSGSouth Asia, Coimbatore, India. 432 pp.

Singh, M., Malik, I., Dittus, W., Sinha, A., Belsare, A., Walker, S. R., Molur, S., Wright, B., Lenin, J., and Chaudhuri, S. (2007). Action Plan for the Control of Commensal, Non-human Primates in Public Places. Zoo Outreach Organisation (ZOO), Coimbatore, 16 pp.

Website:www.southasianprimatenetwork.org/pdf/Action\%20Plan\%20Monkey $\% 20$ Manners.pdf

Walker, S. (2007). Monkey madness_Educational material for Z.O.O. Zoos' Print 22(2): 1-4.

Walker, S. (Ed.). (2007). South Asian Primates, NEW Education Tools for Teaching About South Asian Primates. Zoo Outreach Organisation (ZOO), IUCN/SSC Primate Specialist Group (PSG) South Asian Primate Network (SAPN), Coimbatore. CD-ROM.

Walker, S. and Molur, S. (compilers). (2007). Guide to South Asian Primates for Teachers and Students of All Ages. Zoo Outreach Organisation (ZOO), PSG South Asian Primate Network (SAPN), and the Wildlife Information Liaison Development (WILD), Coimbatore, India. 64 pp.

Zoo Outreach Organisation (ZOO). (2007). Monkey Manners Education Packet. English, Hindi, and Tamil. Zoo Outreach Organisation, Coimbatore, 7 components.

Zoo Outreach Organisation (ZOO). (2007). Drama Kits: Free-Ranging Monkey Conflict. Zoo Outreach Organisation (ZOO), Coimbatore.

\section{Publications}

\section{Primate Conservation}

Editors: Anthony Rylands and Russell Mittermeier, the publication is supported by the Center for Applied Biodiversity Science (CABS) at 
Conservation International (CI), the Los Angeles Zoo, the Department of Anatomical Sciences at the State University of New York, Stony Brook, and the Margot Marsh Biodiversity Foundation. Two issues were published; No. 21 (2006) and 22 (2007).

\section{IUCN/SSC Primate Specialist Group Regional Newsletters}

Volume 13 (2005) of Neotropical Primates was completed with regular issues 1-3 and a supplement issue: "The Ecology and Conservation of the Muriqui (Brachyteles): Reports from 2002-2005"; guest editors Karen B. Strier, Luiz Paulo Pinto, Adriano Paglia, Sérgio Mendes, and Onildo Marini-Filho. Anthony Rylands retired as editor in 2006, and the new editorial team, including Erwin Palacios (e.palacios@conservation.org), Liliana Cortés-Ortiz (Mexico), Júlio César Bicca-Marques (Brazil), Liza Veiga (Brazil), Eckhard Heymann (Germany), Jessica Lynch-Alfaro (USA), Ernesto Rodríguez-Luna and Brenda Solórzano (Mexico), published Volume 14 (1-3).

Two issues of Lemur News $(2006,2007)$ were published by Jörg Ganhzorn (ganzhorn@zoologie.uni-hamburg.de) and his team. Jatna Supriatna (j.supriatna@conservation.org) and Ramesh Boonratana launched a revamped edition of the journal Asian Primates Volume 1(1) 2008 that contained only articles, and Ardith Eudey (eudey@aol.com) continues to maintain an electronic Asian Primates newsletter. The newsletters are available on the PSG website http://www.primate-sg.org/.

\section{Primate Field Guides}

Sally Walker and Sanjay Molur compiled the Guide to South Asian Primates for Teachers and Students of All Ages, published in 2007. Three laminated, foldout pocket field guides were also published (series editors R. A. Mittermeier and A. B. Rylands): Monkeys of the Atlantic Forest of Eastern Brazil, The Monkeys of the Guianas (French Guiana, Guyana, and Suriname), and The Primates of South Asia.

Mittermeier, R. A., Coimbra-Filho, A. F., Kierulff, M. C. M., Rylands. A. B., Mendes, S. L., Pissinatti, A., and Almeida, L. M. de. (2007). Monkeys of the Atlantic Forest of Eastern Brazil: Pocket Identification Guide. Illustrated by Stephen D. Nash. Conservation International Tropical Pocket Guide Series, Conservation International, Arlington, VA.

Walker, S. and Molur, S. (compilers). (2007). Guide to South Asian Primates for Teachers and Students of All Ages. Zoo Outreach Organisation (ZOO), PSG South Asian Primate Network (SAPN), and the Wildlife Information Liaison Development (WILD), Coimbatore, India. 64 pp.

Mittermeier, R. A., Rylands, A. B., Van Roosmalen, M. G. M., Norconk, M. A., Konstant, W. R., and Famolare, L. 2008. Monkeys of the Guianas: Guyana, Suriname, French Guiana. Pocket Identification Guide. Illustrated by Stephen D. Nash. Conservation International Tropical Pocket Guide Series, Conservation International, Arlington, VA.

Molur, S., Walker, S., Brandon-Jones, D., Dittus, W., Kumar, A., Singh, M., and Das, J. 2008. South Asian Primates. Pocket Identification Guide. Maps by 
Pravin Kumar. Illustrated by Stephen D. Nash. Conservation International Tropical Pocket Guide Series, Conservation International, Arlington, VA.

X. Workshops and Action Plans

A regional action plan for the Cross River gorilla (Gorilla gorilla diehli) was drawn up as a result of a workshop held in Calabar, Cross River State, Nigeria, in April 2006. It was organized by the Wildlife Conservation Society (WCS) with the Section on Great Apes of the PSG, and supported by the World Wide Fund for Nature's Great Apes Programme, and the Great Ape Conservation Fund of the U.S. Fish and Wildlife Service (USFWS). The action plan presents an assessment of the status of the Cross River gorilla-scattered in 11 locations along the mountainous border region between Cameroon and Nigeria-and a series of recommendations for its conservation for governmental agencies, conservation groups, and donors.

An action plan for the Tonkin snub-nosed monkey (Rhinopithecus avunculus) in Viet Nam was compiled by Le Xuan Canh and Ramesh Boonratana and published in 2006. It was supported by the Institute of Ecology and Biological Resources (IEBR), Hanoi, Primate Conservation Inc., New York, and the South East Asian Primatological Association (SEAPA).

A Conservation Assessment and Management Plan (CAMP) and Population and Habitat Viability Analysis (PHVA) workshop was held for Mexican primates in October 2006, though the final report is still pending. It was organized by the Universidad Veracruzana and the Conservation Breeding Specialist Group (CBSG) - Mexico, at Xalapa, Veracruz, Mexico.

Le, X.C. and R. Boonratana (compilers). 2006. A Conservation Action Plan for the

Tonkin Snub-nosed Monkey in Viet Nam. Institute of Ecology and Biological

Resources (IEBR), Hanoi and Primate Conservation Inc., New York. 37 pp.

Oates, J. F., Sunderland-Groves, J., Bergl. R., Dunn, A., Nicholas, A., Takang, E.,

Omeni, F., Imong, I., Fotso, R., Nkembi, L., and Williamson, L. (2007).

Regional Action Plan for the Conservation of the Cross River Gorilla (Gorilla gorilla diehli). IUCN/SSC Primate Specialist Group, and Conservation International, Arlington, VA. $36 \mathrm{pp}$.

\section{Funding Primate Research and Conservation}

The Margot Marsh Biodiversity Foundation provides funding to U.S.-based institutions, allowing for grants of up to $\$ 25,000$. Deadlines for submission of applications are March 1 and September 1 of each year. Applications can be sent to Dr. William R. Konstant, 403 Poplar Road, Flourtown, PA 19031, USA; e-mail: bkonstant@houstonzoo.org.

The Primate Action Fund provides awards of up to \$5000. Proposals are considered when they are received. Payments can be made through institutions such as NGOs, zoos, or universities worldwide, but not to individuals. Applications for these grants can be sent to Anthony B. Rylands, Center for Applied Biodiversity Science, Conservation International, 2011 Crystal Drive, Arlington, VA 22202, USA, e-mail: a.rylands@conservation.org. Seventy awards were given out from March 2006 to March 2008, totaling \$267,699. 